\title{
Subsídios à Reformulação da Educação Médica com Especial Referência à Microbiologia
}

\begin{abstract}
RESUMO
Proposiçào de desdobramento da císciplina Microbiologia médica do cicko básico do curso de Mecticina, en duas: Microbiologia biomédica e Iniciação à Infectologia. A primeira, tecnologia da Microbiologia biomédica, com carga horária redizida no cicho básico, de execuscoes individuais e demonstraçós a grupos de estudantes, tomando a Bacteriologia como algo paradigmático (com vulatis .Muraviss oportus. nos). E a segunda to cicio clínico, com mior carga horária, predominantemente conceitual em Clínica e. Epidemiologia (definiçues, glossário de terminologia instrumental) de integração vertical a disciplinas do) ciclo clinico, en particular Moléstias Infecciosas, stricto sensu. (Clinica médica) e sua Epidemiologia (Medicina social preventiva).
\end{abstract}

\section{INTRODUÇÃO}

C) admirável desenvolvimento da Microbiologia, no século XIX, fê-la revelar-se como especialidade biomédica autônoma no sentido exato, dedicada que era, após as fundamentais contribuições metodológicas de Pasteur (1822-1895) e Koch (1843-1910), a exames não da pessoa do paciente, como a competência da clinica o exige, mas dos mais diferentes tipos de material colhidos do paciente para serem submetidos a exames laboratorias, de ordem complementar e de valor conclusivo para determinar a "identidade biológica"dos micróbios encontrados. (O micróbio é o seu mister, objeto direto de sua investigação. As identidades encontradas c isoladas em cultura pura eram confrontadas com a situação clínico-epidemiológica do paciente, inclusive se isento de sintomatologia. Esses cotejamentos ininterruptos, em que se estudavam surtos e epidemias fornecedores de casos clínico-epidemiológicos da doença, levavam a conclusōes confirmativas de diagnóstico bilateral clínico-microbiológico.

Os resultados confirmavam as suspeitas com tanta freqüència que o período foi cognominado áureo para a nova ciência da Microbiologia em Medicina: ciência em plena fase de consolidação observacional, experimental e conceitual, valorizando-se definitivamente, em sua contribuiçāo complementar ao diagnóstico do caso em posiçào conclusiva idônea. Só bem mais tarde ficou estabelecido que "certa" doença infecciosa, causada especificamente por micróbio de "determinada" identidade, não bastava para que se produzisse a moléstia necessariamente, como ficou evidente nos casos (nada raros) de portadores-sãos. Entāo, a rigor, esse micróbio não encerrava toda a etiologia (etio, causa em grego), não encerrava toda a

Microbiológica;

Educação médica. 
"carga da causa". Ele não poderia ser o agente etiológico da doença, como foi abusivamente denominado à época; mas, sem dúvida, o agente infeccioso, adequadamente denominado hoje.

Desse modo, a Microbiologia foi alcançando plena autonomia científica com sua decisāo idônea e singular, na determinaçāo dos agentes microbianos patogênicos, e nāo patogênicos da flora normal. Métodos e processos que, ainda hoje, continuam a evoluir de modo que possam oferecer, além de segurança tecnológica, prontidão de resultados para agilizar a conclusão diagnóstica do caso de suspeito a definitivo. Em face da feliz especificidade das reaçōes imunolńgicas, a Imunologia, associada à Micobiologia médica, tornou-se, de diversas maneiras, imprescindivel, sublinhando com exatidāo que, se o paciente reage a determinado micróbio, foi por ele atacado; nāo importa que essa reaçāo assuma diferentes aspectos em cada exemplo onde atua.

Mas, apesar do exposto, a carga horária atribuida à Microbiologia médica no ciclo básico (disciplina do $2^{\circ}$ ano nas faculdades de Medicina), em geral, tem sido, muito restrita. Esta avaliaçāo crítica é, entretanto, factual, considerando: a) a importância da disciplina ante as muito elevadas prevalências de Moléstias Infecciosas, stricto sensu, isto é, produzidas por agentes infecciosos microbianos; b) na volta recente ao cenário de Saúde Pública de doenças epidêmicas que se julgavam (com inaceitável simplismo ante a complexidade, de regra, dos fenômenos biológicos) estarem "eliminadas" do país, como a cólera, a febre amarela, a dengue; e, noutra faixa, "controladas", a peste, a tuberculose e a hanseníase. Se bem que os sanitaristas do passado já haviam notado que, moléstias transmissiveis "controladas", voltavam ao campo, mais cedo ou mais tarde, após o afrouxamento, nunca impune, das medidas de controle; c) até mesmo o aparecimento de uma, nunca antes identificada que se tornou surpreendentemente ameaçadora à humanidade como um todo, como é a AIDS, que exorbita dos quadros a que estávamos acostumados; e outras, de revelaçāo também recente, mas de pouca extensāo aparente; d) como aquilatar a esperança outra vez simplista, de tratamento anti-infeccioso em moldes de alta eficiência, iniciados na década de $40 \mathrm{com}$ as novas quimioterapias $e$ antibioticoterapias aparentemente capazes de eliminarem e/ou controlarem moléstias infecciosas graves e hoje, termos de aceitar como fato contumaz. o surgimento da resistência, até multi-instalada, dos micróbios a esses medicamentos ? Como aceitar que o estreptococo do Grupo A, já de tāo diversificada patogenicidade, ainda tenha revelado ultimamente, linhagens novas, capazes de "digerirem tecidos moles vivos" ("flesh-eating kind") como recentemente se verificou em sua nova capacidade patogênica, agora necrotizante também ? E outras tantas pergun- tas no campo do que melhor pareciamos conhecer, que ficam com respostas suspensas, e até quando?

Considerando-se como meta a alcançar no curso de graduaçāo em Medicina, tanto sob o ponto de vista biomédico (Tecnologia) como médico (lnfectologia) um certo grau de proficiência caracterizado por influência educativa de algum modo, marcante, fica o penoso registro de que "a clássica" disciplina Microbiologia (Médica) do curso de Medicina, hoje, pode admitir uma aplicaçāo mais proficua da preciosa carga horária, que lhe corrige a situação antiga de nāo satisfazer melhor nem ao seu aspecto biomédico, nem ao seu aspecto médico. Uma carga horária maior, entretanto, deveria reservar-se para a Iniciaçāo à Infectologia, pois a ênfase deve ser colocada, de preferência, se houver necessidade de escolha, pelos aspectos específicos da vocação médica.

Para o Conteúdo Programático seria criada uma nova disciplina médica, a denominar-se Iniciaçāo à Infectologia (Clínicoepidemiológica) no $3^{\circ}$ ano (ciclo clínico) em desdobramento da, e complementaçāo à disciplina tradicionalmente denominada Microbiologia (Médica), do $2^{\circledR}$ ano (ciclo básico) que passaria a denominar-se Microbiologia biomédica (tecnologia, métodos e processos).

Julgamos necessário que a programaçāo incluísse nāo somente questōes sugeridas pelo Professor encarregado da Iniciaçāo à Infectologia, mas também pelos seus colegas das disciplinas clínicas para as quais a nova disciplina deseja oferecer-lhes integraçāo vertical complementar básica: Doenças Infecciosas stricto sensu da Clínica Médica e sua Epidemiologia (Medicina Social Preventiva). I'or outro lado, a ênfase na complementaçāo médica que traria esta disciplina é dirigida ao discernimento claro de conceitos fatuais clínico-epidemiológicos da Infectologia de interesse fundamental na atuação do médico como clínico, envolvendo os chamados atos médicos (exclusivos, e indelegáveis, exceto formalmente), e que, em doenças transmissíveis assumem aspectos clínicos de diagnóstico, epidemiológicos, preventivos e terapêuticos.

Numa parte geral do curso de Iniciação à Infectologia dar-se-ia importância também aos aspectos históricos da evoluçāo das incipientes conjecturas na interpretaçāo das ocorrências de casos isolados (esporádicos), como surtos epidêmicos e epidemias de dimensōes catastróficas, que tiveram repercussāo no passado (citemos o exemplo da erradicação da variola).

A correta definição dos conceitos pode parecer, pejorativamente, uma montagem "teórica" dos fatos, se assim considerados, mas significam muito na prática: por exemplo, os micróbios, agentes imputáveis de patogenicidade nāo sāo, conforme já referido 
anteriormente, etiológicos como foram denominados na consolidação da microbiologia médica, mas, a rigor mostraram-se infecciosos, pois dependem da conjunção de três ordens de fatores: $1^{\circ}$ ) do ser infectado, $2^{\circ}$ ) do meio ambiente total e, enfim, $3^{\circ}$ ) do próprio micróbio. E esse conhecimento completo pode ser utilizado na Medicina Preventiva.

O notável microbiologista franco-americano René Jules Dubos, do Instituto Rockefeller (Nova York), ainda na década de 40 defendia o plano de que poderia ser de sumo interesse prático para a medicina social preventiva aprofundar as condiçōes de história natural que tornam possivel o portador-são: i. é, aquele equilíbrio alcançado entre agredido e agressor tornando pacifica a sua convivência. Numerosas observaçōes confirmaram e esclareceram a moléstia infecciosa no paciente e a infecção no portador-são. A moléstia infecciosa, stricto sensu, é um drama resultante de três fatores em suas variáveis:

1) A susceptibilidade-imunidade e resistência inespecífica do paciente;

2) grau variável de patogenicidade do micróbio;

3) influência dos meios-ambiente:

a) ecológico-epidemiológico;

b) sócio-econômico - em suas alternativas favoráveis ou desfavoráveis aos humanos enfrentando os micróbios patogênicos.

Exemplos:

$1^{0}$ - erradicação

a) da variola, efetivada; por meio de vacinação em massa;

b) da poliomielite, em processo de efetivação (?); por meio de vacinação em massa.

$2^{\circ}$ - eliminação

da febre amarela; passagem de urbana silvestre por alteração do meio ambiente ecológico-epidemiológico e vacinação dos expostos.

$3^{\circ}$ - controle ou eliminação

a) da tuberculose ] por nível suficientemente elevado do meio ambiente sócio-

b) da hanseniase l econômico-cultural e vacinação anti-tuberculose dos expostos.

Uma tarefa fundamental do Professor hoje, ante a massa de informações e conhecimentos lançada pelos meios de comunicação que chegam continuamente à nossas bibliotecas, tornou-se - contrariando o antigo e popular adágio, de que "o saber não ocupa lugar", já que o saber, hoje, ocupa lugar (se não puder ser, de alguma forma, utilizado) não apenas um problema relativamente simples de substituir matéria obsoleta pontual por aquisiçōes cientificas de recente consubstanciação (como tão freqüentemente, e não de há muito, foi evoluindo nosso conhecimento, por exemplo, sobre a Familia Enterobacteriaceae). Isso constitui um tipo de tarefa que, em certos casos, demanda uma atitude de descompromissada eqüanimidade e capacidade de integração de conhecimentos para alcançar uma escolha adequada - ponto que talvez só as felizes intuiçōes consigam alcançar.

É fato consumado que os estudantes de Medicina, há algum tempo, não escolhem, a disciplina Microbiologia (Médica) como especialidadelaboratorial da biomedicina, senão, excepcionalmente. Esse desinteresse leal pela disciplina de Microbiologia biomédica (tecnologia: processos e métodos) não pode e não deve ser recriminado.

Ao contrário, só pode merecer nosso respeito pela louvável fidelidade que essa atitude significa para com a sua vocação médica confirmada; pela qual, isto sim, se sentem naturalmente atraidos e - sintoma decisivo - pessoalmente valorizados.

Enfim, o que eles vieram almejando e esperavam ao conseguirem matrícula tão competitiva numa Faculdade de Medicina, foi começar desde logo sua vivência médica, mergulhando numa atmosfera distinta da laicidade anterior, distinta $\mathrm{e}$ indiscutivelmente valorizante, impressionados pelos modelos que lhes são novos, de comportamento de seus professores, sobretudo ante os pacientes, e já aprendendo a executar, responsavelmente, tarefas profissionais sob supervisão próxima "em benefício dos pacientes", na lição hipocrática fundamental (curativos, injeçōes, primeiros socorros, medida da pressão arterial e da temperatura, registro sistemático de anamneses, uso do estetoscópio, freqüência de pulsos, estágios no serviço de radiografias, eletrocardiografias, nos laboratórios de análises clínicas, não para todos, mas para os que se decidiram por especialidades correlatas, etc.).

Na dependência determinante da carga horária disponivel dentro da inextensível carga horária total do curso de Medicina, realmente nāo cremos que se deva despender parte desse precioso fator (carga horária) com estudos e treinamentos tecnológicos para alcançar proficiência teórica e prática em tipos de atividade e trabalho que os estudantes de medicina hoje jamais pensariam utilizar em suas vidas profissionais de clínicos, como essa situação atual, e de há muito, vem demonstrando de forma inequívoca em circunstâncias que nos parecem irreversiveis. 


\section{SUMMARY}

CONTRIBUTION TO A READIUSTMENT ON MEDICAL EDUCATION, WITH SPECIAL REFERENCE TO MICROBIOLOGY

Proposal of unfolding for the programmatic contents of the medical and para-medical ciscipline of short duration. Microbiology, basic cycle, into two disciplines; the first, para-medical Microbiology (technology), at the same basic cycle, taking bacteriology as a paradigmatic examplè with opporture: mulatis mutandis of tecnical procedures (demonstrations to groups of studentes and students personal performances) as an expresed sufficient adequacy for medical education. And a second. new discipline of rather long duration, Initiation to Infectology, clinical cycle. This discipline (concepts, definitions, glossary of instrumental terminology on practical facts) should show an interdisciplinary vertical integration to disciplines of clinical cycke, particularly Infectious Diseases stricto sensu (Clinical Practice), and to their Epidemiology (Social Preventive Medicine).

\section{KEY WORDS}

Medicine, History of; Communicable Iiseases; Microbiological Techniques; Education, Medical.

\section{AGRADECIMENTOS}

O autor agradece à Escola de Higiene e Saúde Pública da Universidade John Hopkins, MD, U.S.A., da qual recebeu medalha de bronze pelo qüinquagésimo aniversário de sua graduaçāo "Master of Public Health", 1945-46.

Obs.: A ABEM parabeniza-se com o emérito Professor distinguido com a medalha de bronze pela Escola de Higiene e Saúde Pública da Universidade John Hopkins, MD, U.S.A., na passagem do 50aniversário de sua graduaçāo "Master of Public Health".

\section{REFERÊNCIAS BIBLIOGRÁFICAS}

1. BENENSON, Abram S., ed. El Control de las enfermedades transmisibles en el hombre. 15. ed. [s.l.]: OPAS, OMS, 1992. Pub. Cient. n" 538.

2. BYINGTON, C. A. B. Pedagogia simbólica: a construçāo amorosa do conhecimento do ser. Rio de Janeiro: Recurd/Rosa dos Tempos, 1996, 355 p.
3. CRISTIE, Andrew Barnett. Infectious diseases. Encyclopaedia Brit. Inc., London, v. 9, p. 532-559, 1974.

4. GERMANI, G. Industrialization and modernization. Encyclopaedia Brit. Inc., London, v. 9, p.520-527, 1974.

5. GONÇALVES, Ernesto Lima. Qualidade do ensino: o professor: interaçāo professor aluno. In: XX CONGRESSO BRASILEIRO DE EDUCAÇ.̄̄O MÉDICA, 1982, Ribeirāo P’reto. Anais... Ribeirāo Preto: $A B E M, 1982.155$ p. p. 55-72.

6. HANCOCK, Elise. The Squeeze is On. Johns Hopkins Magazine, v. 47, n. 5 , p. $48-55,1995$.

7. LENETTE, E., (ed). Manual of clinical microbiology. 5. ed. American Society for Microbiology, 1992.

8. MARCONDES, Eduardo et al. Integraçāo horizontal e vertical de disciplinas na graduaçāo médica. São Paulo: Documentos CEDEM, n. 6. p. 1-81, maio, 1995.

9. RELMAN, A. S. Médicos e convênios: um choque de culturas. Jornal CREMESP, p.10-11, nov., 1996.

\section{Endereço do autor}

Rua Garibaldi, 2619

14025-190 - Ribeirāo Preto - SP 